\title{
Decentralized Justice: A Comparative Analysis of Blockchain Online Dispute Resolution Projects
}

\author{
Yann Aouidef ${ }^{1}$, Federico Ast $^{2 \star}$ and Bruno Deffains ${ }^{3}$ \\ ${ }^{1}$ Paris Center for Law and Economics Laboratory, Paris II Panthéon-Assas and Coopérative Kleros, Paris, France, ${ }^{2}$ Faculty of \\ Business Administration, Universidad Austral, Pilar, Argentina and Coopérative Kleros, Paris, France, ${ }^{3}$ Paris Center for Law and \\ Economics Laboratory, Paris II Panthéon-Assas, Paris, France
}

In recent years, the digital economy has experienced a growing number of transactions. Traditional dispute resolution methods such as court and international arbitration are ineffective for handling a large volume of small value claims across national borders. Decentralized justice is a new approach to online dispute resolution that combines blockchain, crowdsourcing and game theory in order to produce resolution systems which are radically more efficient than existing methods. This article offers a review of the

OPEN ACCESS

Edited by:

Marta Poblet,

RMIT University, Australia

Reviewed by:

Pablo Cortes,

University of Leicester,

United Kingdom

Andreas Freund,

Independent Researcher, San Diego,

$C A$, United States

Jason Allen,

Humboldt University of Berlin,

Germany

*Correspondence:

Federico Ast

federico@kleros.io

Specialty section:

This article was submitted to

Blockchain for Good,

a section of the journal

Frontiers in Blockchain

Received: 21 May 2020 Accepted: 13 January 2021

Published: 16 March 2021

Citation:

Aouidef Y, Ast F and Deffains B (2021) Decentralized Justice: A Comparative Analysis of Blockchain Online Dispute

Resolution Projects.

Front. Blockchain 4:564551.

doi: 10.3389/fbloc.2021.564551 decentralized justice industry and of the key players participating in it. It presents a number of key dimensions of the industry and reviews the mechanism design choices made by these different platforms. Finally, it discusses a growth hypothesis for the industry and how it may grow in the future.

Keywords: blockchain, arbitration, online dispute resolution, smart contracts, cryptoeconomics

\section{INTRODUCTION}

In 1958, the New York Convention on the Recognition and Enforcement of Foreign Arbitral Awards ${ }^{1}$ (New York Convention, 1958) was signed with the goal of addressing the rising disputes of international commerce and investment. It was intended to provide a key governance infrastructure to resolve large scale trade and investment disputes involving governments and multinational corporations.

In recent years, the rise of the internet and digital commerce created a new breed of disputes of a different nature from the multi-million dollar cases for which the New York Convention framework was built. The new economic reality holds a large number of small international claims for a few thousand dollars in cases such as a software development contract, a remote team that conducted a crowdfunding campaign but did not deliver what was promised, or an online fraud (Nappert and Ast, $2020)^{2}$

\footnotetext{
1"Recognizing the growing importance of international arbitration as a means of settling international commercial disputes, the Convention on the Recognition and Enforcement of Foreign Arbitral Awards (the Convention) seeks to provide common legislative standards for the recognition of arbitration agreements and court recognition and enforcement of foreign and nondomestic arbitral.awards."

${ }^{2} \mathrm{As}$ an illustration, the average transaction in e-commerce is $\$ 102$ while the cost alone of filing a dispute in a commercial court in the Netherlands, the country with the lowest costs compared to the European Union and North America\#, is $€ 15$. Source:The E-Commerce Industry's 12 Most Critical Metrics, Guidingmetrics; International Comparisons of litigation costs prepared for the U.S. Chamber Institute for Legal Reform by NERA Economic Consulting, Institute for legal reform; Cost of litigation in The Netherlands, Netherlands commercial Court.
} 
As Ethan Katsh, father of online dispute resolution, said: the power of technology to resolve disputes is exceeded by the power of technology to generate disputes (Katsh and Rabinovich-Einy, 2019b). Traditional dispute resolution systems (e.g., state courts, international arbitration) seem inadequate for resolving the vast amount of the disputes that happen in online transactions. It is estimated that from 3 to $5 \%$ of online transactions end in a dispute (Mania, 2015). The transnationality of e-commerce combined with the requirements for shorter and cheaper procedures give reason to expect rapid growth of the online dispute resolution industry (Schultz, 2002).

Even though ODR services have been in existence since the 1990 s, the industry has failed to reach the growth potential that some expected in the early days (Deffains and Gabuthy, 2006). But over the last couple of years, new projects arising from a field called decentralized justice are giving new air to this industry by promising an innovative way to provide a fast and affordable dispute resolution process for the new small value claims of the digital economy. The field is the result of a convergence of online dispute resolution, blockchain, international arbitration and mechanism design.

The goal of this article is to provide a descriptive and comparative review of three projects that are playing a pioneering role in the decentralized justice industry: Kleros, Aragon and Jur. We will analyze similarities and differences in the design choices made by their respective teams and how this may impact the evolution of the industry. In the second section, the paper discusses the nascent industry of decentralized dispute resolution platforms within the framework of decentralized justice. The third and fourth sections describe the three most prominent platforms along a set of characteristic dimensions and present differences, similarities between the platforms and their limitations. In the last two sections, we consider possible adoption scenarios for decentralized justice in general and dispute resolution in particular.

\section{THE INDUSTRY OF DECENTRALIZED JUSTICE}

Ronald Coase argues that under certain conditions cooperation between agents yields good results in terms of economic efficiency and social capital (Coase, 1937). The ability of blockchain to facilitate the transfer of value and self enforce agreements results in lower transaction costs. The blockchain's characteristics of disintermediation, immutability and transparency make it possible to envisage very broad applications in industries as varied as e-commerce, finance, insurance, healthcare and social media. However, in order for these predictions to materialize, a number of developments are required.

Smart contracts are "smart" enough to self execute as written in their code. But they cannot resolve situations that are open to interpretation by the parties. Litigation arising between parties reduces the speed and automation of the transactions' execution resulting in high legal uncertainty and high transaction costs (Coase, 1960), losing all the gains created by smart contracts. Moreover, analysis has been made through the framework of
Dispute Resolution Possibilities Frontier (DRPF) which mapped and described four institutional possibilities (private orderings, arbitration, courts and the regulatory state) in terms of disorder costs $^{3}$ and dictatorship costs ${ }^{4}$ to see how existing dispute resolution mechanisms assist with smart contract disputes (Allen et al., 2019).

Decentralized justice platforms are a form of "digital courts" supported by blockchain technology whose purpose is the settlement of disputes by crowdsourcing jurors under economic incentives to provide fair (Ast and Dimov, 2018) rulings. The procedure in these platforms is encoded as smart contracts $^{5}$ on a blockchain which seeks to guarantee legal certainty ${ }^{6}$. Decentralized justice platforms aim to provide a way to resolve matters of interpretation inherent to smart contracts thus lowering transaction costs and enabling the thriving of many decentralized applications built on blockchain.

From this perspective, the emergence of decentralized justice can be interpreted as an efficient institutional answer to the economic problem of coordination between agents, in such a way to reduce transaction costs (Deffains and Gabuthy, 2006). For instance, modern e-commerce has brought a new category of dispute to the fore, namely small-scale transnational disputes. As these traditional dispute resolution channels (including the courts) are poorly suited to this new category, blockchain-based "decentralized justice" platforms provide a viable alternative. For instance, some argue that decentralized justice enables more nuanced crypto solutions and produces greater certainty in the process (Kaal and Calcaterra, 2018).

It is decentralized because the process is driven by peers, built on blockchain technology and cannot be controlled by any single agent. It is justice in the sense that it claims to provide just solutions to cases submitted to it. Thanks to their innovative mechanism design, decentralized justice systems have the potential of providing a fast, cheap and fair dispute resolution method, especially suited to the resolution of claims in e-commerce, freelancing, crowdfunding and many other cases from the digital economy or either in more traditional disputes ${ }^{7}$.

\footnotetext{
${ }^{3}$ Disorder costs arise from private expropriation or a failure to coordinate. ${ }^{4}$ Dictatorship costs arise from public expropriation.

${ }^{5}$ Much development has been done in connection to resolving legal issues through smart contracts and ODR. For references: -Schmitz, Amy J. and Rule, Colin, Online Dispute Resolution for Smart Contracts (June 26, 2019). 2019 Journal of Dispute Resolution 103; University of Missouri School of Law Legal Studies Research Paper No. 2019-11.-Rabinovich-Einy, Orna and Katsh, Ethan, Blockchain and the Inevitability of Disputes: The Role for Online Dispute Resolution (2019). J. Disp. Resol. (2019).

${ }^{6}$ Understood as a principle in national and international law which holds that the law must provide those subject to it with the ability to regulate their conduct.

${ }^{7}$ For reflection on the question if Decentralize justice, for instance Kleros, can fit with current jurisdictional frameworks: Dmitry, N (2019). Due Process In Kleros Consumer Dispute resolution. https://drive.google.com/ file/d/1eyQDC3QYNE8gAjt0meZ6ImhL3n47zr_3/view [Accessed November 18, 2020].
} 


\begin{tabular}{lcc} 
& You vote $\mathbf{0}$ & You vote 1 \\
\hline Others vote 0 & $p$ & 0 \\
Others vote 1 & 0 & $p$ \\
\hline
\end{tabular}

\section{THE KEY PLAYERS OF DECENTRALIZED JUSTICE}

In early 2020, the decentralized justice industry is composed of three key players: Kleros, Aragon and Jur.

Kleros was founded by Federico Ast and Clément Lesaege in May 2017 (Kleros Website, 2020). Development efforts for the Kleros protocol are coordinated by Coopérative Kleros, a Société Coopérative d'Intérêt Collectif (SCIC) incorporated in France. Launched on the Ethereum blockchain in July 2018, Kleros was the first decentralized justice platform to become operational and the most used at the time of this writing ${ }^{8}$. As of November 2020, nearly 500 disputes have been resolved and around 400 users participate as jurors in the platform ${ }^{9}$. This has generated around $\$ 123,000$ in arbitration fees paid to jurors ${ }^{10}$.

Coopérative Kleros follows a hybrid strategy which targets both use cases native from the blockchain industry and also mainstream use cases where traditional actors from the ODR industry are already active. As for applications in the blockchain industry, the company targets dispute resolution for escrow transactions, token curated registries (the use of decentralized jurors and economic incentives for compliance verification) and dispute resolution for oracles. As for mainstream applications, Coopérative Kleros fosters the development of so-called "layer two companies" building solutions on top of the Kleros protocol Kleros blog (2020).

Aragon was founded in February 2017 by Luis Cuende and Jorge Izquierdo in Spain and is currently incorporated in the Aragon Association which is a non-profit entity based in Zug, Switzerland Aragon Wiki (2020). The vision of the Aragon project is to provide software tools for users to create decentralized autonomous organizations (DAOs) (Aragon Website, 2020). Aragon launched their decentralized court in November 2019 with a mechanism design heavily inspired by Kleros work (Aragon, 2020). According to Aragon sources, the court has 239 jurors Aragon Network (2020) but do not inform about the number of resolved disputes.

In the case of Aragon, the court service seems focused on providing arbitration services for DAOs within the Aragon ecosystem. The main use case envisaged in the white paper Aragon Whitepaper (2020) is the resolution of disputes on voting proposals in DAOs that may contradict the "constitution" of the organization. Through a vote on the

${ }^{8}$ To learn more about how the Kleros platform works, read Kleros White Paper: https://kleros.io/whitepaper_en.pdf. Also read Kleros Yellow Paper with the social choice theory research currently conducted by Coopérative Kleros: https://kleros. io/whitepaper_long_en.pdf

${ }^{9}$ http://klerosboard.com

${ }^{10} 256 \mathrm{ETH}$ were paid as fees to jurors as of November 17th, 2020. http:// klerosboard.com
Aragon court, the proposal could be declared "unconstitutional" and overturned.

Jur was founded in October 2017 by Alessandro Palombo and Giotto De Filippi in Switzerland through a "Société civile/Société commerciale" under Swiss law ${ }^{11}$. At the time of this writing, Jur still has not released a working product. The project's white paper claims that the system will cover a wide variety of cases through three different courts: the Court Layer (a system similar to a traditional ODR system with traditional arbitrators for higher value disputes, which they claim can produce legally binding rulings), the Open Layer (a system more akin to Kleros with a decision making logic based on collective intelligence) and the Community Layer (a kind of private court with specifics rules defined by creators). Jur strategy seems focused on enterprise use cases. While they started building on Ethereum, in July 2018 they switched to the blockchain Vechain in an attempt to focus on the enterprise segment (Vechain, 2020). Figure 1 summarizes a number of key elements of these projects.

\section{DIMENSIONS OF DECENTRALIZED JUSTICE}

Decentralized justice projects have made different choices in a number of dimensions regarding mechanism design. Similarities and differences between projects include the following dimensions:

\section{Case Complexity}

Different mechanism choices affect the different types of disputes that platforms can handle. All platforms can resolve binary cases where the decision is to be made only between two options. Some platforms claim to be able to resolve non-binary cases.

\section{Jury Selection}

Different platforms have made different choices on the selection process of jurors, in particular, the possibility of vetting jurors based on specific criteria such as skills. Kleros and Aragon do not offer a mechanism to select jurors based on specific criteria (all users can be drawn as jurors if they stake tokens) while Jur allows for jurors to be vetted.

\section{Reputation Effects}

Different platforms have different approaches on the accumulation of reputation as jurors. Kleros and Aragon rely solely on cryptoeconomic incentives created by a token while Jur takes juror reputation into consideration.

\section{Appeal Mechanism}

Different platforms made different choices in the possibility for users to appeal rulings. Some platforms allow appealing rulings (Kleros and Aragon) while others do not (Jur).

\footnotetext{
${ }^{11}$ Jur model is divided in three types of layers, of which only the "Open Layer" seems to conform to the definition of decentralized justice by Ast and Deffains. The "Court Layer" seems to operate as a streamlined arbitration method.
} 


\begin{tabular}{|l|l|l|l|}
\hline & Kleros & Aragon & Jur \\
\hline Strategy Definition & $\begin{array}{l}\text { Hybrid strategy } \\
\text { targeting both the } \\
\text { blockchain market } \\
\text { and mainstream } \\
\text { use cases }\end{array}$ & $\begin{array}{l}\text { Arbitration for } \\
\text { DAOs of the } \\
\text { Aragon ecosystem }\end{array}$ & $\begin{array}{l}\text { Mainstream } \\
\text { corporate } \\
\text { cases }\end{array}$ \\
\hline Use Cases & $\begin{array}{l}\text { Mostly simple } \\
\text { transactions where } \\
\text { traditional ODR } \\
\text { methods are too } \\
\text { slow or expensive }\end{array}$ & $\begin{array}{l}\text { Governance } \\
\text { proposals } \\
\text { conflicting with } \\
\text { DAO rules }\end{array}$ & $\begin{array}{l}\text { Different methods } \\
\text { for different kinds } \\
\text { of conflicts }\end{array}$ \\
\hline Partnerships & $\begin{array}{l}\text { BPI, Thomson } \\
\text { Reuters, Layer 2 } \\
\text { Companies, } \\
\text { CRED Laboratory } \\
\text { from Paris II } \\
\text { Panthéon Assas }\end{array}$ & $\begin{array}{l}\text { DAOs from the } \\
\text { Aragon Ecosystem }\end{array}$ & $\begin{array}{l}\text { VeChain, Lexit, } \\
\text { BitNautic, Scidex, } \\
\text { 4cLegal, Radboud } \\
\text { University }\end{array}$ \\
\hline Blockchain & $\begin{array}{l}\text { Ethereum } \\
\text { Etherengum but }\end{array}$ & $\begin{array}{l}\text { Ethereum } \\
\text { building their own } \\
\text { blockchain }\end{array}$ & VeChain \\
\hline
\end{tabular}

FIGURE 1 | Key facts about the projects and their strategies ((Kleros Website, 2020), (Jur Website) and (Aragon Whitepaper, 2020)).

\section{Governance Model}

In Kleros and Jur, the platform token is used for governance (e.g., decide software upgrades). In Aragon, a different token is used.

\section{Subscription Fees}

In Aragon, parties are required to pay a regular subscription fee to have the right to use the court. In Kleros and Jur, fees are only paid when a dispute arises.

\section{Trustlessness}

Kleros and Aragon are built on fully decentralized blockchains with trustless transactions in the sense that any user can join as a node. Jur is built on VeChain, which uses a Proof of Authority consensus algorithm with trusted nodes.

Figure 2 presents a number of similarities and differences between these projects in the aforementioned dimensions:

Different design choices entail different trade-offs. Currently, the main economic mechanism used is the Schelling Point, which is, in game theory, a solution that people tend to choose by default in the absence of communication. Kleros, Aragon and Jur are using this mechanism. The idea of using this in the blockchain ecosystem was first introduced by Vitalik Buterin, one of the founders of the Ethereum blockchain, because a number of blockchain-based systems involve voting that, implicitly or explicitly, can be seen in the context of Schelling point based games (taking decisions for a DAO basically). A simple representation of a Schelling game could be the next one:

The theory behind Schelling points is that if everyone expects everyone else to vote truthfully, then their incentive is to also vote truthfully in order to comply with the majority, and that's the reason why one can expect others to vote truthfully in the first place; a selfreinforcing Nash equilibrium (Buterin, 2015a). Nonetheless, Social
Choice Function $^{12}$ (to which Multiple Choice Schelling Game belong) also suffers from a number of limitations:

- They miss some desired properties as clone independence ${ }^{13}$ : For instance, let's suppose there are only two options among all the options offered to the jurors that deal with letting one of the parties more delay for improving the object of the transaction (the development of a website for instance). And let's suppose that these two delay options differ only from a few days that do not permit to clearly define a better delay (for instance a situation where we know that we need more delay but we don't know if how much more days need exactly for improving the website). Then in this kind of context, despite the fact that more delay is the better solution, jurors could deviate from the delay options in order to not take the risk to choose the wrong delay. Then clone independence is a desired property in order to avoid these kinds of deviations from the best solution by jurors.

- They suffer from Pre-Revelation attacks where jurors could decide to collude with revealing their vote. Many Anti-PreRevelation Games have been proposed (Buterin, 2015a).

- They suffer from the $p+\varepsilon$ attack, a type of bribing attack where an agent tries to corrupt the jurors' decision through a promise (with a variable credibility) to pay those voting for some specific decision. Also, many mechanisms have been proposed to avoid these attacks (Buterin, 2015b).

\footnotetext{
${ }^{12} \mathrm{~A}$ social choice function, or SCF, is a map $\mathrm{f}: \mathrm{L}(\mathrm{A})^{\mathrm{n}} \rightarrow \mathrm{C}(\mathrm{A})$ that returns a nonempty set of alternatives for each profile of strict preferences.

${ }^{13} \mathrm{~A}$ set of candidates are considered to be clones if all voters rank them consecutively. Then deleting a clone from every voter's list should not change whether any other candidate outside the set of clones wins or loses.
} 


\begin{tabular}{|c|c|c|c|}
\hline & Kleros & Aragon & Jur \\
\hline $\begin{array}{l}\text { Does the platform } \\
\text { solve binary } \\
\text { cases? }\end{array}$ & Yes & Yes & Yes \\
\hline $\begin{array}{l}\text { Does the platform } \\
\text { solve non binary } \\
\text { cases? }\end{array}$ & $\begin{array}{l}\text { Yes, but in limited } \\
\text { cases. }\end{array}$ & No & Yes \\
\hline $\begin{array}{l}\text { Does the platform } \\
\text { provide a } \\
\text { mechanism for } \\
\text { selecting jurors } \\
\text { based on skills? }\end{array}$ & No & No & Yes \\
\hline $\begin{array}{l}\text { Does the platform } \\
\text { allow for user } \\
\text { reputation? }\end{array}$ & No & No & Yes \\
\hline $\begin{array}{l}\text { Does the platform } \\
\text { allow to appeal } \\
\text { rulings? }\end{array}$ & Yes & Yes & No \\
\hline $\begin{array}{l}\text { Is the platform a } \\
\text { child of a more } \\
\text { global DAO? }\end{array}$ & No & Yes & No \\
\hline $\begin{array}{l}\text { What is the } \\
\text { purpose of the } \\
\text { token? }\end{array}$ & Staking & Staking & $\begin{array}{l}\text { Payments or } \\
\text { Staking, } \\
\text { depending on the } \\
\text { court. }\end{array}$ \\
\hline $\begin{array}{l}\text { Is the token used } \\
\text { for the court DAO } \\
\text { governance? }\end{array}$ & Yes & No & Yes \\
\hline $\begin{array}{l}\text { Does the platform } \\
\text { have regular } \\
\text { subscription fees? }\end{array}$ & No & Yes & No \\
\hline $\begin{array}{l}\text { Is it built on a } \\
\text { trustless } \\
\text { blockchain? }\end{array}$ & Yes & Yes & No \\
\hline
\end{tabular}

FIGURE 2 | Different mechanism design choices ((Kleros Website, 2020), (Jur Website) and (Aragon Whitepaper, 2020)).

Also, more broadly:

- When there are three or more alternatives, then every Social Welfare Function ${ }^{14}$ (whose Multiple Choice Schelling Game) that is weakly Paretian and IIA $^{15}$ must be a dictatorship Procaccia et al., 2016);

- Under very limited assumptions on a social choice function and payoff structure, inevitably there will be situations

${ }^{14}$ Function that accepts as input a so-called profile $p=(1, \ldots, \mathrm{n})$ of preferences, one for each individual, and maps it to a single preference order, which we can think of as representing a suitable compromise.

${ }^{15}$ Independence of irrelevant alternatives: if $A$ is preferred to $B$ out of the choice set $\{A, B\}$, introducing a third option $X$, expanding the choice set to $\{A, B, X\}$, must not make $\mathrm{B}$ preferable to $\mathrm{A}$. where participants are incentivized to deviate from the notions of honesty (George, 2020).

Schelling point mechanism designs have limitations for resolving non-binary cases but remains the most efficient option for simpler cases (typically, binary). While it is not clear what the "right answer" is in terms of design, the important thing is to have consistency between the design and the type of use cases the platform seeks to serve.

\section{ADOPTION OF DECENTRALIZED JUSTICE}

The decentralized justice industry is at an early stage. In May 2020 , the combined number of users of decentralized justice platforms is lower than 1,000 . Adoption is expected to increase as 


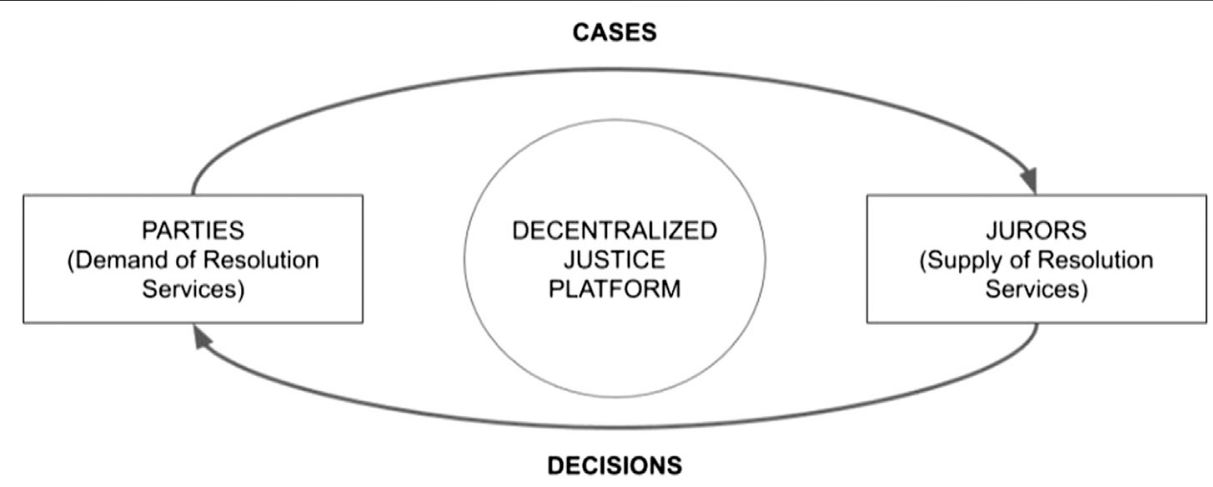

FIGURE 3 | Decentralized justice platforms act as cryptoeconomic mechanisms to coordinate supply and demand of resolution services.

the applications from the blockchain ecosystem gain adoption and decentralized justice platforms offer a more efficient and trustless way of securing transactions compared to alternatives such as government courts, international arbitration and traditional online dispute resolution methods.

Since they are based on innovative game theoretical mechanism designs and frictionless payments rails, decentralized justice systems can offer an adjudication system which is radically cheaper and faster than alternatives while at the same time guaranteeing a fully transparent procedure.

An important question is: how are decentralized justice platforms going to grow from their current early stage into highly efficient providers of "justice as a service"?

In order to answer this question, we can conceptualize decentralized justice systems as marketplaces which coordinate the supply and demand of resolution services. Parties (e.g., two users who use a decentralized justice platform to resolve an e-commerce dispute) are the demand side of the marketplace. They consume an adjudication service which is provided by jurors through the platform cryptoeconomic mechanism. Jurors are the supply side of the marketplace. They sell their time and skills in order to process the relevant information and produce decisions.

Traditional legal and arbitration systems have high costs because the institutional arrangements in which they operate tend to give legal experts a monopoly on the provision of legal services: lawyers have a monopoly on legal consultation and magistrates have a monopoly on judgments having imperium and exequatur. This results in a limited supply of adjudication services and, therefore, a high equilibrium price.

Thanks to their cryptoeconomic mechanisms, decentralized justice platforms can leverage the knowledge and work of individuals with a specific expertise which is not necessarily recognized by the system of legal skills development. As illustrated in Figure 3, as a higher number of agents participate as service providers, the supply of resolution services increases which drives the cost per case at a level that is not possible to attain by traditional methods. The quality of the adjudication services is ensured, not by reliance on a professional body and codes of conduct, but by purely economic mechanisms.

This does not mean that decentralized justice platforms are bound to replace legal professionals in the resolution of legal claims. However, it does mean that they are able to resolve a number of disputes types for which legal professionals are not a good fit because of their high cost.

Decentralized justice platforms rely on network effects to produce low cost dispute resolution (Figure 4). When parties use a decentralized justice platform, this generates demand for resolution services which drives up the price and incentivizes jurors to join the network. The increased supply of resolution services drives resolution costs down in a market adjustment mechanism toward equilibrium. With each turn of the cycle, as more users join the network, an increased specialization generates better, cheaper and faster decisions.

As is typically the case in the early stages of business models based on network effects, decentralized justice networks face a "chicken and the egg problem": what should come first, cases to be solved (demand) or jurors to solve them (supply)? What is the incentive for jurors to join the network if there are no cases to be solved (hence, no revenue to be made)? And what is the incentive for parties to use the platform if there are not enough jurors to resolve cases? Decentralized justice platforms face this "chicken and the egg" problem in order to get the network effects started.

An open question is whether the decentralized justice market structure will show the "winner takes all" behavior as many digital industries based on network effects. As a network grows larger, it typically benefits from economies of scale which creates an advantage over its competitors. In the case of decentralized justice, this could manifest itself in the following way: a platform gaining an advantage would result in a higher number of cases and jurors, which would allow for efficiency gains bringing in turn more cases and a higher incentive for users to join the juror pool. At some point, the network could become large enough so that the efficiency gains are hard to overcome by followers.

It is yet to be seen if the decentralized justice industry will indeed show this type of behavior. An argument could be made in the sense that cost efficiencies (being the lowest cost network) is not the only relevant competitive variable. Another important variable can be the ability of a network to comply with some institutional conditions such as ethical or regulatory requirements. For example, even though Uber has succeeded in building the larger drivers and passengers network, it is forbidden in a number of jurisdictions that consider 


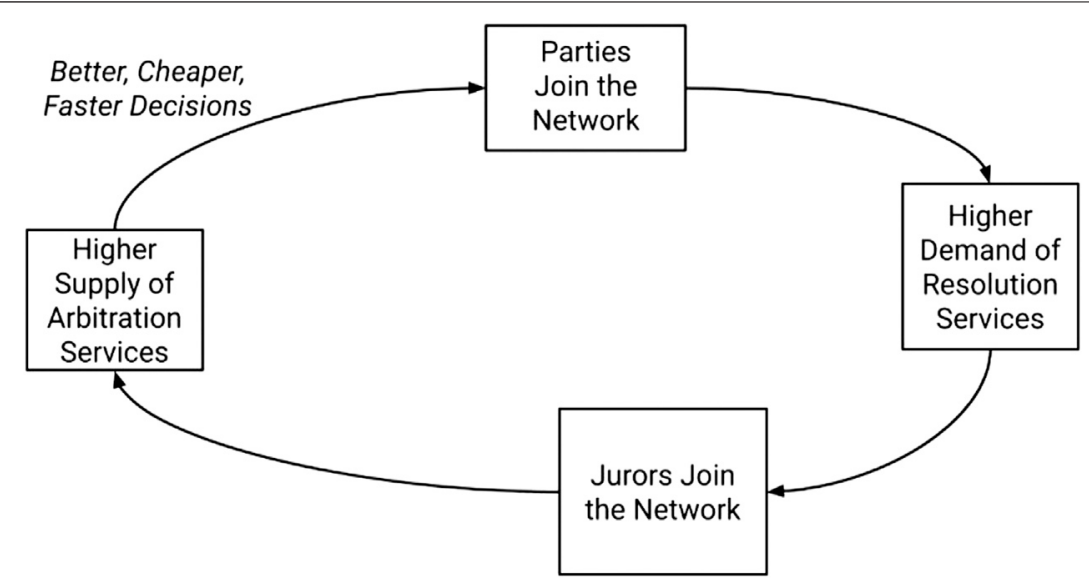

FIGURE 4 | The network effects driving the growth of a decentralized justice platform.

that it does not comply with the appropriate regulatory conditions. In those jurisdictions, other local players may be the leader.

Similarly, different mechanism designs adopted by different decentralized justice platforms may be institutionally better suited for different types of use cases. If this is indeed the case, the industry could end being fragmented into different providers. For example, Platform A, as the lowest cost provider, would become the leader in use cases where cost is the critical competitive variable. However, the mechanism design chosen by Platform A could not be appropriate, for ethical or regulatory reasons, for other types of applications. These types of use cases could be served by Platform B. Even though this is not the lowest cost provider, it could have a better fit from an institutional perspective.

This is where a deeper understanding of the similarities and differences between the mechanism designs of the decentralized justice projects could help understand the potentially different use cases they could serve.

\section{CONCLUSION}

The global legal market is worth over one trillion ${ }^{16}$ and the blockchain market is estimated at $\$ 1.5$ billion $^{17}$. In May 2020, the combined market value of decentralized justice platforms was still under $\$ 10$ million and the combined number of users still under 1,000. This evidentiates that the decentralized justice industry is still in its early days.

But the rapidly rising volume of low value digital transactions promises a growing market for an efficient and fair method for dispute resolution. For instance, the value of cross-border payments worldwide in 2019 reached $\$ 2.58$ billion and is expected to reach $\$ 3.56$ billion in $2022^{18}$. This is expected to

${ }^{16}$ Size of the legal services market worldwide from 2013 to 2021, Statista.

${ }^{17}$ Blockchain Technology Market Size, Share, and Trends Analysis Report By Type, By Component, By Application, By Enterprise Size, By End Use, By Region, And Segment Forecasts, 2019-2025, Grand View Researcher.

${ }^{18}$ Value of cross-border payments worldwide from 2016 to 2022 by type, Statista. increase as a larger number of transactions start to be conducted in cryptocurrency, bringing a near frictionless experience to international payments.

In this article, we have defined the industry of decentralized justice, introduced the key players in the market, presented a number of key dimensions of the industry and discussed different options on how the market might grow and evolve in the future.

The world economy is rapidly changing and requires a new institutional framework to secure transactions. This announces radical changes in legal practices. As industry expert Richard Susskind said: "The legal industry will change more in the coming 20 years than in the previous $200 " 19$.

Naturally, these changes will generate important debates from a legal perspective, where for example dissenting judgments are recognised as having value for legal development. What makes blockchain technology a powerful tool for promoting disintermediation and decentralised coordination (i.e. a trustless technology) could also constitute one of its greatest limitations for some commentators (Katsh and Rabinovich-Einy, 2019a), especially when it comes to collective deliberation. Collective action is mainly about reaching a compromise between conflicting interests and values whereas blockchain technology operates via distributed consensus and an exit-based conflict resolution system. Thus, it is important to consider how decentralized justice could promote the general interest, produce common goods and create a collective sense of justice through a more marketbased approach to conflict resolution.

An important part of this transformation is likely to come from the field of machine learning and the use of legal analytics. Another part will come from the emerging field of decentralized justice which incorporates blockchain,

${ }^{19}$ Technology's Impact on the Legal Profession: An Interview with Richard Susskind-Part 1, Priorilegal. 
crowdsourcing and mechanism design into dispute resolution procedures.

This article has reviewed different design choices made by the pioneers in the industry of decentralized justice. Behind every decision, there are trade-offs and path dependency effects that will influence the strategies of these platforms in the future.

\section{REFERENCES}

Allen, W. E. D., Lane A, M., and Poblet, M. (2019). The governance of blockchain dispute resolution. Harvard Negotiation Law Rev. 25, 75-101. doi:10.2139/ssrn. 3334674

Aragon (2020). Aragon association. Available at: https://anj.aragon.org/ (Accessed May 21, 2020).

Aragon Network (2020). Aragon Network. Available at: https://stats.aragon. network/ (Accessed November 18, 2020).

Aragon Website (2020). Aragon Website. Available at: https://aragon.org/ (Accessed November 18, 2020).

Aragon Whitepaper (2020). Aragon Whitepaper. Available at: https://github.com/ aragon/whitepaper (Accessed November 18, 2020).

Aragon Wiki (2020). Aragon association, overview. Available at: https://wiki. aragon.org/association/overview/ (Accessed November 18, 2020).

Ast, F., and Dimov, D. (2018). Is Kleros a fair dispute resolution system? Kleros blog. Available at: https://blog.kleros.io/is-kleros-a-fair-dispute-resolutionsystem/ (Accessed November 18, 2020).

Buterin, V. (2015a). The P + epsilon Attack. Available at: https://blog.ethereum. org/2015/01/28/p-epsilon-attack/ (Accessed November 18, 2020).

Buterin, V. (2015b). On anti-pre-revelation games. Available at: https://blog. ethereum.org/2015/01/28/p-epsilon-attack/ (Accessed November 18, 2020).

Coase, R. H. (1937). The nature of the firm. Economica 4 (16), 386-405. doi:10. 1111/j.1468-0335.1937.tb00002.x

Coase, R. (1960). The problem of social cost. Chicago, IL: The University of Chicago Press, 1-44.

Deffains, B., and Gabuthy, Y. (2006). Efficiency of online dispute resolution: a case study. Commun. Strat. 201-224.

George, W. (2020). Voting systems for Multiple choice schelling games. Available at: https://kleros.io/static/yellowpaper_en-28d8e155664f3f21578958a482f33bd1.pdf (Accessed November 18, 2020).

Kaal, W., and Calcaterra, C. (2018). Crypto transaction dispute resolution. Chicago, IL: Business Lawyer.

Katsh, E., and Rabinovich-Einy, O. (2019a). Blockchain and the inevitability of disputes: the role of online dispute resolution. J. Dispute Resolut. 2019, 48.

\section{AUTHOR CONTRIBUTIONS}

YA was in charge of data collection and writing. FA provided the main thesis of the article based on his industry experience. BD contributed overseeing the process and with the theoretical aspects of law and economics.

Katsh, E., and Rabinovich-Einy, O. (2019b). Digital justice: technology and the internet of disputes. Oxford University Press. doi:10.1093/acprof:oso/ 9780190464585.001 .0001

Kleros blog (2020). Layers 2. Available at: https://blog.kleros.io/kleros-layer-2/ (Accessed May 21, 2020).

Kleros website (2020). Kleros court. Available at: https://kleros.io/ (Accessed May 21, 2020).

Mania, K. (2015). Online dispute resolution: the future of justice. Available at: https://www.sciencedirect.com/science/article/pii/S2351667415000074 (Accessed November 18, 2020).

Nappert, S., and Ast, F. (2020). Decentralized justice: reinventing arbitration for the digital age?. Global Arbitration Rev.

New York Convention on the Recognition and Enforcement of Forein Arbitral Awards (1958). Arbitral. Available at: https://www.uncitral.org/ (Accessed May 21, 2020).

Procaccia, A., Conitzer, V., Brandt, F., Lang, J., and Endriss, U. (2016). Handbook of computational social choice. Cambridge, England: Cambridge University Press, 6-7.

Schultz, T. (2002). Online dispute resolution (ODR): résolution des litiges et ius numericum. Cairn 48, 153. doi:10.3917/riej.048.0153

Vechain (2020). Whitepaper. Available at: https://www.vechain.org/whitepaper/ \#bit_v48i3 (Accessed May 21, 2020).

Conflict of Interest: Even though the article is written in a balanced and objective way, FA is employee and President at Coopérative Kleros. YA is employee and researcher at Coopérative Kleros.

The remaining author, $\mathrm{BD}$, declares that the research was conducted in the absence of any commercial or financial relationship that could be construed as a potential conflict of interest.

Copyright (c) 2021 Aouidef, Ast and Deffains. This is an open-access article distributed under the terms of the Creative Commons Attribution License (CC $B Y)$. The use, distribution or reproduction in other forums is permitted, provided the original author(s) and the copyright owner(s) are credited and that the original publication in this journal is cited, in accordance with accepted academic practice. No use, distribution or reproduction is permitted which does not comply with these terms. 